\title{
1. The nature of courts
}

\section{Nicholas A. Robinson}

\section{A. INTRODUCTION}

The human quest for just and equitable behaviour is rooted deep in the evolution of homo sapiens. Humans expect just conduct in all spheres of social endeavour. Parsing how we come to know what is just, or not, is the subject of much thinking by myriad philosophies and religions. Law both shapes and codifies norms of justice. Human societies organize the architecture of their decision-making to fulfil, at least in its fundamental aspects, their expectations for attaining just conduct. The judiciary has evolved as an essential vehicle for arriving at just decisions.

The symbols chosen to reflect law reflect this dimension of human nature. The ancient Chinese pictogram for law, $F A$, graces the centre of the seal of the IUCN Academy of Environmental Law.

$F A$ is evocative of the quest for justice. The right hand side features the mythical figure $Z h i$, a force of nature, a moral and righteous creature, who with a single horn can determine right from wrong. Zhi is seen judging the human, in the upper left corner. The act of judgment is symbolized by water, which is the most fundamental of elements, running downhill

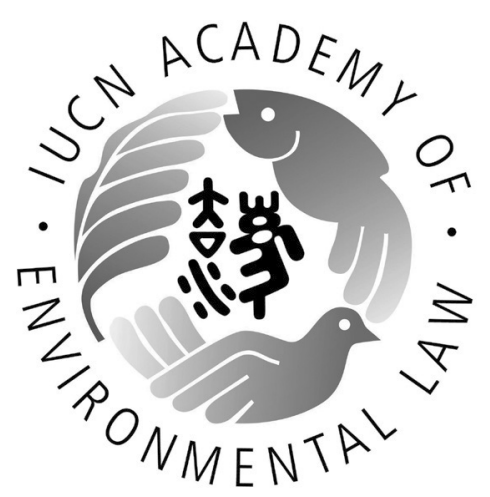

Figure 1.1 The seal of the IUCN Academy of Environmental Law 
or going away from the unjust to seek that equilibrium of a level plain below. The image inspires us to be moral and just. The symbol $F A$ was embraced by Buddhism as the truth of the universe and a path to return to one's innate goodness. ${ }^{1}$ A statue of Zhi graces the entrance of the Law School of Wuhan University, one of the world's leading centres for environmental law. ${ }^{2} F A$ entwines nature, the act of judgment, and justice.

$F A$, this most ancient of justice's symbols, is about the nature of judging humans in nature. In western traditions, other symbols would emerge, such as Ma'at in Egypt or Themis in Greece, or Justitia in Rome. ${ }^{3}$ Justice in western symbolism portrays a woman, blindfolded or not, holding a sword or not, seated or standing. Images of Lady Justice grace court houses around the world. Scales - whether for measuring grain or the merits of a legal argument - are held by Lady Justice, and sometimes others, or are also depicted alone, to symbolize fairness in judging. These western symbols are anthropocentric, focusing on the human aspiration for legal regimes that are just. Do these more contemporary symbols of justice move away from imaging the nature of justice?

For most indigenous peoples, the nature of justice is not viewed apart from the people. The elders and community administer justice of all dimensions, and there is little need for an external symbol. ${ }^{4}$ Where adjudicatory systems thrive within customary law, traditionally there is no need for statute books or physical images.

All legal systems reflect the fundamental instinct of the human species

1 Cindy Chan, 'Story of ancient divine creature of Justice Speaks to Issues of Morality and Law-making', in Epoch Times (23 January 2014) at https://www. theepochtimes.com/chinese-character-for-law-f $\%$ C7\%8E- $\%$ E6\%B3\%95_3917.html.

2 Professor Wang Xi, Shanghai Jioa Tong University, and Nicholas Robinson agreed to adopt the $F A$ symbol for the Academy's logo while preparing the first Colloquium held in Shanghai in 2002, which launched the IUCN Academy of Environmental Law. The IUCN Academy of Environmental Law's Governing Board later confirmed the choice of the logo design. The statue of Zhi greeted IUCN Academy law professors in Wuhan each day as we entered the law school each day for our 7 th Colloquium in 2009.

3 Judith Resnik and Dennis Curtis, Representing Justice: From Renaissance Town Halls to 21 st Century Democratic Courtrooms (Yale University Press, 2010).

4 See, for example, the traditional Inuit system of justice, which is integral to a stable community, focused on healing circles, reconnecting offenders to the land and nature, remediation, healing, spiritual values (the Angakkuit, a shaman, can see people's wrong-doings). To reflect expectations of contemporary juridical systems, the Nunavut Court of Justice, based in Iqaluit but riding circuit to communities every 6 weeks in 2 years, is Canada's only single level court (1999). See Mariano Aupilaarjuk, et al., eds., Perspectives on Traditional Law (Nunavut Arctic College), at www.nac.nu.ac/publications/vol2/pdf/. 
to seek to advance just relations. Wherever there exists a tribe or community, or a state or international community of states, each individual expects that to live or endure within a justly ordered society is preferable to being in one that abjures justice. Where courts come to be invested with legitimacy, they become stewards of justice. Without recourse to justice, grievances fester and lead to unrest. Providing access to justice leads to peaceful relations. In short, the expectation of, and the quest for justice is an evolved norm, a 'hard-wired' human instinct, in all humans. ${ }^{5}$ Courts have naturally emerged as the forum through which a community seeks to attain just relations for its members.

This chapter explores how humans have come to seek environmental justice through courts. This theme may be explored in four dimensions:

(a) the emergence of legal norms for stewardship of nature, since the end of the nineteenth century, and how the nature of courts recognizes these environmental rights;

(b) the constancy of societal recourse to judicial tribunals to secure environmental justice, whether in ancient times (such as the Verderers courts of England in the thirteenth century) or today (such as in the establishment of environmental courts in China in 2015);

(c) the judicial capacity to advance the environmental rule of law, which is becoming a worldwide phenomenon, and is being furthered by the establishment of the Global Judicial Institute on the Environment; and

(d) illustrations of how comparative environmental law may enhance judicial decision-making.

When a community enacts laws governing relations between humans and nature, it is the tendency of its courts to apply environmental principles and laws for stewardship of nature, for environmental justice.

\section{B. NATURE IN JUSTICE}

Environmental courts now number more than 1,500 in some 50 nations. ${ }^{6}$ This rapid expansion of environmental adjudication is more than just

5 The evolutionary roots of environmental law are set forth in Nicholas A. Robinson, 'Evolved Norms - A Canon for the Anthropocene', in Christina Voigt, ed., Rule of Law for Nature, pp.46-71 (Cambridge University Press, 2013).

6 George and Catherine Pring, Environmental Courts and Tribunals (UN 
a response to the adoption of environmental statutes and treaties since the 1972 Stockholm UN Conference on the Human Environment. Environmental law is a mature field, and like all sectors of law entails dispute resolution. Several symposia have explored the emergence of these environmental courts and tribunals. ${ }^{8}$

The recent emergence of specialized environmental courts reflects something deep in the human psyche. Diverse nations and legal systems independently are empowering courts to adjudicate environmental questions. What does the emergence of environmental courts reveal about how societies can better cope with the gathering crises of the Anthropocene Epoch? ${ }^{9}$ The emergence of courts affords a window through which to discern the cultural evolution of human nature and its quest for justice about nature. These expanding juridical roles follow upon enactment of laws reflecting consensus about the principle of sustainability and duties for environmental protection.

The ecologist Aldo Leopold articulated the basic moral norm for humans to sustain nature as part the 'community of life'. Leopold called it the 'land ethic'. ${ }^{10}$ It reflects an empathy with other living beings, and a

Environment Programme)athttp://wedocs.unep.org/bitstream/handle/20.500.11822/ 10001/environmental-courts-tribunals.pdf?sequence $=1$

7 See Nicholas A. Robinson and Lal Kurukulasuriya, Manual on International Environmental Law (UN Environment), at https://digitalcommons.pace.edu/lawfacu 1ty/791.

8 See, e.g. The 14th annual Colloquium of the IUCN Academy of Environmental Law, 'The Environment In Court', PluriCourts at the University of Oslo, at http:// iucnael2016.no, and also http://www.iucnael.org/en/news/latest-news/225-generalnews/513-14th-annual-colloquium-of-the-iucn-academy-of-environmental-lawoslo-20; and see Nicholas A. Robinson, 'Ensuring Access to Justice Through Environmental Courts', 29 Pace Environmental Law Review 363 (Winter 2012), introducing the Special Edition on Environmental Courts and Tribunals, at https:// digitalcommons.pace.edu/pelr/vol29/iss2; and 'The Role of the Environmental Judiciary', in 3 Journal of Court Innovation (winter 2010), by the New York State Judicial Institute and Pace University, at https:/law.pace.edu/sites/default/files/ IJIEA/01_TableOfContentsFinal.pdf.

9 Richard Monastersky, 'Anthropocene: The Human Age', Nature, vol. 919, issue 7542 (11 March 2015), at https://www.nature.com/news/anthropocene-the-hu man-age- 1.17085

10 Aldo Leopold, A Sand County Almanac (Oxford University Press, 1949) at pp. 204-5: 'All ethics so far evolved rest upon a single premise: that the individual is a member of a community of interdependent parts. His instincts prompt him to compete for his place in the community, but his ethics prompt him also to co-operate (perhaps in order that there may be a place to compete for). The Land Ethic simply enlarges the boundaries of the community to include soils, waters, plants, and animals, or collectively: the land ... In short, a land ethic changes the 
reciprocity akin to what all religions posit in the 'golden rule' for relations among humans. Leopold identified the motivation for human decisions to set aside natural protected areas, and to provide for wider stewardship of nature. The 'land ethic' independently has emerged as a component of the principle of 'sustainable development'. ${ }^{11}$

There are many instances of humans acting in light of this principle, and doing so over many generations. In the early twentieth century, Russian biologists concluded that humans had a moral duty, a commandment (zapovyed) to preserve vast areas of wild nature, to preclude human intervention and to let the nature be. Russia's zapovedniki are the world's largest system of protected natural area. They observed their centenary in 2017. That year England saw the 800th anniversary of its Forest Charter. The year before, 2016, was the centenary of the US National Parks Service. Virtually all nations have established park systems, with protected natural areas.

The quest for environmental justice, to observe a 'land ethic' norm, grew enormously just before and early after 1900 . The conservation laws enacted then in United Kingdom or the United States of America were more than just a reaction to the externalities of the industrial revolution. Humans valued the beauty in nature, and understood how natural systems served society. For example, as open countryside was being lost in England, London sued to protect the former royal forest of Waltham Abbey, and acquired it to preserve as parkland, Epping Forest. ${ }^{12}$ In Queen Victoria's time, Parliament enacted legislation to preserve many former royal forests, such as the New Forest or the Forest of Dean. In North America, Congress set aside Yellowstone, Yosemite and other natural areas as the world's first national parks. From these origins, governments worldwide established protection for natural areas. ${ }^{13}$ As pollution became

role of Homo sapiens from conqueror of the land-community to plain member and citizen of it. It implies respect for his fellow-members, and also respect for the community as such.' The norm can be seen to have a religious foundation, or a natural law foundation or a foundation in evolutionary biology. Such a norm is widely acknowledged as the basis for the duty to protect the environment, as expressed in law.

11 The progression of sustainable development from a 'soft law' policy to a recognized principle of law is set forth in Björn Bischoff, 'Sustainability as a Legal Principle', pp. 167-90 in Klaus Bosselmann and Ronald J. Engel, The Earth Charter: A Framework for Global Governance (2010).

12 https://www.cityoflondon.gov.uk/things-to-do/green-spaces/epping-forest/ heritage/Pages/history-of-Epping-Forest.aspx.

13 IUCN advances protected areas through its World Commission on Protected Areas. See, e.g. Marc Hockings, et al., Evaluating Effectiveness at https://www.iucn. 
a public nuisance, these laws for nature conservation were complemented by laws to restore and protect environmental quality. Following the 1972 United Nations Stockholm Conference on the Human Environment, virtually all nations established their environmental laws and ministries of the environment.

In the wake of such legislation, including regimes for environmental impact assessment, ${ }^{14}$ roles emerged for the courts. In diverse nations, Supreme Courts issued landmark decisions. ${ }^{15}$ At the international level, courts such as the European Court of Human Rights have found and applied environmental human rights in a wide range of instances. ${ }^{16}$ The importance of access to justice in environmental decision-making was confirmed as Principle 10 of the 1992 Rio Declaration on Environment and Development, ${ }^{17}$ and in the Aarhus Convention. ${ }^{18}$ Judicial recognition of the right to the environment and the environmental rule of law confirm

org/content/evaluating-effectiveness-framework-assessing-management-protectedareas-2nd-edition. The United Nations maintains a roster of these areas. https:// www.unep-wcmc.org/resources-and-data/united-nations-list-of-protected-areas.

14 Environmental Impact Assessment (EIA) was first fashioned and enforced by the courts, in the National Environmental Policy Act in the USA, 42 US Code 4321. Frederick R. Anderson, NEPA In The Courts (1973). As States adopted EIA laws, it came to be reflected in Principle 17 of the Rio Declaration on Environment and Development, and was found by the International Court of Justice to have become a customary rule of International Law in Concerning Pulp Mills on the River Uruguay (Argentina v. Uruguay), 2010, at http://www.icj-cij.org/en/ case/135. EIA is a subject of environmental adjudication in most nations.

15 See, e.g. the decision in Oposa v. Factoran, which can be accessed at https:// www.lawphil.net/judjuris/juri1993/jul1993/gr_101083_1993.html (Supreme Court of the Philippines), or M.C. Mehta and Anr. Etc. vs. Union Of India and Others, 1986 SCR (1) 312 (Supreme Court of India), see also a summary of the ten most important Indian cases at https://blog.ipleaders.in/environment-law-judgment/; or the first of many cases in the United States: Storm King Preservation Conference v. Federal Power Commission, 354 F. 2d 608 (2d Cir., 1965) at https://elr.info/sites/default/files/ litigation/1.20292.htm.

16 Human Rights and the Environment (2011), at http://www.justiceandenviron ment.org/_files/file/2011\%20ECHR.pdf

17 'Environmental issues are best handled with the participation of all concerned citizens, at the relevant level. At the national level, each individual shall have appropriate access to information concerning the environment that is held by public authorities, including information on hazardous materials and activities in their communities, and the opportunity to participate in decision-making processes. States shall facilitate and encourage public awareness and participation by making information widely available. Effective access to judicial and administrative proceedings, including redress and remedy, shall be provided', at http://www. un.org/documents/ga/conf151/aconf15126-1annex1.htm.

18 Aarhus Convention on Access to Information, Public Participation in 
that the human need for justice is a not an amenity, or social value competing among other preferences. Justice guides cooperation. When society denigrates justice, it leads to atomistic and problematic relationships. Restoring sustainable relationships between people and nature depends upon environmental justice.

Attitudes of public civic virtue expect that all legal systems, particularly the executive or legislative branches, should behave honestly. As formal court systems have come to be established, at least during the past two centuries beginning with the 'age of enlightenment', the judicial branch of government has emerged as the arbiter of civic honesty and guarantor of what is just. This is as evident in adjudicating private disputes among individuals or in applying a statute fairly, or in assessing whether a government has followed the rule of law. Even when nations do not maintain an independent judiciary, governments of sovereign states worldwide purport to honour justice. Virtually all have established courts.

Since nations employ courts to administer justice, it should not be surprising that they find specialized environmental courts useful. What does the quest for environmental justice reveal about the role of courts? Why are environmental courts found in more than one-third of all UN Member States? In 2015, China alone opened nearly 600 environmental chambers of its courts, and in that year 230,000 environmental cases were filed against polluters, somewhat overwhelming the new courts. More than coincidence is evident. Individually, governments are creating environmental courts to cope with the environmental disruptions of the impacts of the Anthropocene Epoch. ${ }^{19}$

The Anthropocene's diverse environmental disruptions generate unjust situations. Who has rights to water during droughts, or who deserves compensation after a flood? As laws strive to induce sustainable development, problems of both intra-generational and inter-generation justice arrive in courts. ${ }^{20}$ Conflicts about distributive justice are inevitable. ${ }^{21}$ Humans shape, often inadvertently, a plethora of unjust situations in the world. In Pakistan, hugely devastating Indus River floods in 2010 (July-November)

Decision-Making, and Access to Justice in Environmental Matters, (1998) at http:// ec.europa.eu/environment/aarhus.

19 Will Steffen, Paul J. Crutzen and John R. McNeill, 'The Anthropocene: Are Humans Now Overwhelming the Great Forces of Nature?' Ambio, vol. 36, No. 8 (Dec. 2007), Royal Swedish Academy of Sciences.

20 Joerg Chat Tremmel, ed., Handbook of Intergenerational Justice (Edward Elgar, 2006).

21 Andrew Dobson, Justice and the Environment: Conceptions of Environmental Sustainability and Theories of Distributive Justice (Oxford, Clarendon Press, 1998). 
were assessed by a formal Inquiry of the Pakistan Supreme Court. ${ }^{22}$ Similar flooding in 2007-16 on Missouri River in the USA resulted in extensive claims against the US government. ${ }^{23}$

The climate models all show the likelihood of unprecedented disruptions due to the changing hydrologic cycle, a consequence of climate change. As both people and nature suffer, the volume of claims for justice will increase. Judicial capacity will need to be enhanced to address the new volume of cases. It is unclear how the deliberative judicial process, such as that of the European Court of Human Rights on environmental rights ${ }^{24}$ can be scaled up to handle large numbers of cases seeking environmental justice.

\section{EMPOWERING COURTS ADJUDICATING HUMANS AND NATURE}

Many nations lack independent and well-resourced courts. Many do not rigorously adhere to the rule of law or where they do then there may be implementation deficits in respect of judicial decisions. Even where courts are well regarded, there are debates about whether justice is attained. As disruptions occur in this contemporary Anthropocene epoch, societies increasingly will need orderly procedures for the aggrieved to access justice. Governments will continue to turn to courts to provide access to justice. This can be seen from ancient examples, such as the roles of Verderers in England from the thirteenth century to the present. It is also evident in the contemporary efforts in China to create a role for the courts in controlling pollution and addressing demands for blue skies and clean waters.

\section{The Verderers of England}

Recognition and application of norms of justice, and the roles for courts, may be examined with reference to the 13th-century Verderers' Court in

22 M.A. Khan, Report of the Flood Inquiry, Supreme Court of Pakistan (2012).

23 Ideker Farms, et al., v. The United States, No. 14-183L (US Court of Claims, decision of Judge Firestone, filed March 13, 2018), at https://ecf.cofc.uscourts.gov/ cgi-bin/show_public_doc?2014cv0183-426-0.

24 Council of Europe, Manual on Human Rights and the Environment (2012 edition). See also the history of how genocide and crimes against humanity emerged out of the gross injustices of the Nazi era in Europe, to provide a platform internationally for justice in the work of an international humanitarian law and environmental law expert, Philippe Sands, East West Street (Knopf, 2016). 
the Forest of Dean in England. Tribunals involving Verderers have existed in England for some nine centuries to oversee the exercise of commoners' rights and the 'liberties of the forest'. ${ }^{25}$ What can the analysis of human struggles about environmental justice in ancient times tell us about human behaviour today?

Is the human quest for building just societies strong enough to sustain human civilizations through the coming disruptions of the Anthropocene? The eight-century saga of the Forest Charter suggests it can be. To document evolution of a cultural norm, such as justice in nature, it is instructive to assess long-term, inter-generational data. An evolved norm is not the reflection of one generation alone.

King William I established extensive 'royal forests' following the Norman conquest of England in 1066. Today 129 still exist. Their preservation reflects a deeply seated human bond with these natural areas. ${ }^{26}$ When King John used his royal power to expropriate the forest lands that sustained England's people and economy in the thirteenth century, so great was the sense of injustice that civil war erupted. In attempts to stem further bloodshed, Magna Carta recognized the right that we now call 'due process of law' and ordered reforms. Environmental rights were a major part of the Magna Carta. Fifteen of the 65 chapters in the Magna Carta dealt with rights in nature. Chapter 48 expressly authorized 12 knights to survey the realm and prepare a report on the King's 'evil customs' in royal forests and unjust behaviour. ${ }^{27}$

Within two months of having affixed his royal seal to the Magna Carta, King John annulled this 'Great Charter'. The civil war resumed. While the civil war raged on, the knights completed their investigation and prepared a report. The result of their formal 'inquiry' became the basis for the Forest Charter of 1217 (Carta de Foresta).

The Forest Charter guaranteed positive rights for 'free men' to gather

25 The legal and environmental history of the Forest Charter appears in Nicholas A. Robinson, 'The Forest Charter' in Daniel B. Magraw et al., Magna Carta and the Rule of Law (American Bar Association, 2014), available at https:// digitalcommons.pace.edu/cgi/viewcontent.cgi?article $=1988 \&$ context=lawfaculty.

26 Multiple generations have used the royal forests sustainably, in many ways, They conserve these resources, and both customary and statutory laws have come to define sustainable use practices. This is not a story of preservation or a park, but rather evidence supporting Edward O. Wilson's thesis in his study Biophilia: The Human Bond With Other Species (1984).

27 Magna Carta's Chapter 45 directed that 'all the evil customs relating to forest and warrens . . . are to be immediately investigated in each county by twelve sworn knights . . . and they are to be completely abolished ...' (https://www.bl.uk/ magna-carta/articles/magna-carta-an-introduction). 
herbs and berries, wood, graze cattle, take honey, keep eyries for hawks, access waters for their mill ponds, or let their pigs eat acorns in the autumn. The King could not seize or tax these essential rights at will. The Forest Charter anticipated the 'bill of rights', which was to come in the seventeenth century. In the Forest Charter, King Henry III and monarchs after him all agreed to forego unjust conduct in the royal forests. The Forest Charter forbad the King from specific, patently unjust acts. Significantly, the Charter also regulated the conduct of courts that adjudicated England's Forest Law, with the expectation that forest rights could be adjudicated more fairly.

The Forest Charter concludes with a declaration worthy of human rights proclamations, such as those that would emerge following World War II. Chapter 17 provides that 'These liberties of the forest and free customs traditionally had, both within and without the Royal Forests, are granted to ... all in our realm. Everyone is also obliged to observe the liberties and customs granted in the Forest Charter. ${ }^{28}$

The Forest Charter is an example of humans seeking justice about their rights in nature. Like Magna Carta, it was motivated by the thirst for justice in restoring shared public rights in nature, in what today are called 'ecosystem services'. Magna Carta also understood that bemoaning unjust conditions and declaring rights was not enough: procedures are needed to investigate and prescribe remedies. This came to be recognized as the rule of law and due process of law. Magna Carta with the Forest Charter brought about reforms in judicial practice, to provide better 'access to justice'. One of the courts, launched more than 800 years ago, the Court of Attachment in the Forest of Dean, still adjudicates the 'liberties of the forest' and enforce 'customs traditionally had'. ${ }^{29}$ Parliament also has reconstituted a Verderers Court in the New Forest, ${ }^{30}$ and authorized Verderers for Epping Forest, ${ }^{31}$ and established conservators and similar offices elsewhere.

Struggles to confirm the rights enshrined in both Magna Carta and the Forest Charter were fought over 400 years before the 'rule of law' was in place. Kings repeatedly tried to eviscerate these rights, and yet the public obliged King Henry III and King Edward I to reinstate or strengthen them, 32 times. The rights of Magna Carta and the Forest Charter became the

28 Chapter 17, Forest Charter, originally in Latin. See Magraw et al., Magna Carta and the Rule of Law.

${ }_{29} \mathrm{http}: / / \mathrm{www}$.deanverderers.org.uk.

$30 \mathrm{http} / / / \mathrm{www}$.verderers.org.uk/court.html.

31 https://www.cityoflondon.gov.uk/things-to-do/green-spaces/epping-forest/ about-us/Pages/Verderers.aspx. 
basis for the petition of right, and subsequent constitutional bills of rights. William Blackstone acknowledged that the Forest Charter was equally as important as Magna Carta, and in 1759 published the definitive texts of 'these two sacred charters' ${ }^{32}$ In the twentieth century human rights, and in the twenty-first century environmental rights, evolved from these roots.

Gradually, and not without great difficulties, repeated invocations of the Forest Charter and appeals to Verderers' tribunals produced a public expectation and norm favouring conserving England royal forests and the English countryside. Although much diminished in acreage, 129 former 'royal forests' thrive today. With natural resilience, they support diverse biodiversity and sequester carbon through photosynthesis, provide ecosystem benefits and afford spiritual relief to all who choose to visit them. They have survived civil wars, the canals and industrialization, the railways, two world wars, the highways and motorways, and suburbanization. Whenever access to the forests was curtailed, protests resulted, including litigation in courts and even civil disobedience. Protection has grown by accretion with each enactment of new environmental laws in each successive generation.

Each generation has reconfirmed prior legal protections accorded to various royal forests. Parliament acted on these values by enacting new legislation and enabling courts to adjudicate the public's environmental rights. This historical account illustrates how humans cooperate to provide effective stewardship of nature. In doing so, they establish justice simultaneously for humans and the entire community of life.

\section{China's Judiciary Environmentally Empowered}

Similar themes are evident today from the decisions in the People's Republic of China to authorize courts to provide environmental justice. Following several years of debate in the People's Congress and the Communist Party, in 2014 China strengthened socialist rule of law by authorizing its courts to hear environmental cases. China independently has arrived at decisions that reflect norms expressed in Principle 10 of the 1992 Rio Declaration on Environment and Development. China's innovative approach aims to restore environmental quality and ecological integrity, based on socialist legality, which is different from the western rule of law. ${ }^{33}$

32 William Blackstone, The Great Charter and Charter of the Forest, with Other Authentic Instruments, to which is Prefixed an Introductory Discourse on the History of the Charters, Oxford: Clarendon Press, 1759. See http://tarlton.law.utexas.edu/ magna-carta/blackstone.

33 See, e.g. Yuwen Li, The Judicial System and Reform in Post-Mao China- 
China's government recognized that its judiciary needed to be enhanced. Too many Provincial Courts had become deferential to local political or economic development priorities, and were not applying laws for environmental protection. Access to the courts was obstructed too frequently. The Party affirmed socialist rule of law in clear terms: 'Fairness is the lifeline of law' and 'Judicial injustice is fatally destructive of social fairness. '34 On 23 October 2014, the Fourth Plenary Session of the 18th Central Committee of the Chinese Community Party took decisions to advance 'the socialist rule of law with Chinese characteristics' and a country under 'the socialist rule of law', ${ }^{35}$ by affirming legislative reforms adopted in April by the People's Congress, and in June 2014 by the Supreme People's Court.

Judicial enforcement of laws against air and water pollution, or for conserving nature, has been and will continue be difficult in China, as it has been in every other country. The socialist rule of law must supplant the rule $b y$ law, which powerful, provincial developers have used to exploit nature unsustainably. Both Chinese Socialist principles and the environment have suffered in recent years. The reforms of 2014, and thereafter, aim to restore both.

The Party and the People's Congress, with the Supreme Court, have determined that China's judicial system will both maintain Party leadership and protect the environment. The courts are instructed to attain environmental justice, or curb corruption. This is congruent with what courts do elsewhere, although some western commentators disagree. One legal commentator observed, 'due process is often viewed in China as a legalistic and unproductive encumbrance. So is the idea of adhering strictly to the law. Reversing this perspective would entail a fundamental and uncomfortable adjustment.'36

Nevertheless, fostering environmental justice through courts has been similarly problematic in all nations. Since all nations employ similar technologies and cause damage to ecological or public health conditions that are also alike worldwide, it is appropriate to share knowledge about judicial remedies that restore the ambient environment. These practical considerations reappear in courts across civil law, common law, or socialist law judicial systems. Best practices can be found in each and, in

Stumbling Towards Justice, (Ashgate, 2014), and Yuwen Li (editor), Administrative Litigation Systems in Greater China and Europe (Ashgate, 2014).

34 Andrew Jacobs and Chris Buckley, 'China Moves To Reinforce Rule of

Law, With Caveats', NY Times, p. A4, col. 1 (24 October 2014).

35 http://news.xinhuanet.com/english/china/2014-10/23/c_133737957.htm.

36 Rebecca Liao, 'China Strives Incoherently for the 'Socialist Rule of Law', Financial Times, p. 11, col. 6 (27 October 2014). 
turn, adapted to each. Other aspects deserve attention as well, of course. Most courts experience problems of corruption. Everywhere, preparatory and continuing legal education for the judges remains under-resourced. Much can be learned while China addresses these issues as it shapes its environmental courts.

The Chinese Communist Party's decisions in 2014 are important for enforcement of the revised 'Environmental Protection Law of the People's Republic of China', ${ }^{37}$ adopted at the 8th Meeting of the Standing Committee of the 12th National People's Congress. They provide individual citizens and non-governmental environmental organizations with the right to sue polluters.

The revised Law for Environmental Protection adds a new Chapter $\mathrm{V}$, entitled 'Information Disclosure and Public Participation'. Article 53 grants citizens and non-governmental organizations 'the right to obtain environmental information', and to 'participate and supervise the activities of environmental protection'. Article 54 requires responsible officials to release publicly 'national environmental quality, monitoring date of key pollutants and other major environmental information'. Local and provincial officials are to include records of violations of environmental laws into the 'social credit archives system and promptly disclose the list of law-breakers to the public'. Article 55 obligates discharges to disclose truthfully the types and volumes of emissions, including violations of applicable emission standards. Article 56 strengthens environmental impact assessment requirements, requiring outreach to the public to explain proposed construction projects and the release of EIA documents. These provisions collectively could bring into Chinese law a number of the best international practices, as contained in the Aarhus Convention, ${ }^{38}$ and its Pollutant Release and Transfer Registry. ${ }^{39}$

Article 57 of the revised Environmental Protection Law provides that citizens and non-governmental organizations 'shall be entitled to report and complain about environmental pollution and ecological damage activities of any units or individual to competent environmental protection administrations or other departments with environmental supervision responsibilities'. Further, if officials fail to fulfil their responsibilities, these same plaintiffs shall 'have the right to report it to the competent higher level governments'. The authorities receiving these reports are to keep the

37 Text is an unofficial translation by the EU-China Environmental Governance Programme, funded by the European Union. See http://www.ecegp. com/index_en.asp.

38 http://www.unece.org/env/pp/acintro.html.

39 www.prtr.net. 
name of the informant who complains confidential, to protect their rights and interests.

Article 58 provides environmental non-governmental organizations (NGOs) with access to the courts. Standing to sue a polluter is accorded to any social organization that has (1) duly registered at the civil affairs department of the people's governments at or above the municipal level, and (2) is specialized in environmental protection public interest activities', and (3) has been active for five consecutive years, and (4) has no record of violations of law. Article 58 provides that 'Courts shall accept the litigations filed by social organizations' that meet these criteria, and has a proviso that 'the social organizations that file the litigation shall not seek economic benefits from the litigation'. This provision for what is known widely internationally as 'citizen suit' brings to Chinese social organizations the right to enforce environmental laws in court.

As Chinese judicial practice develops, it will be important to study how successful NGOs are able to secure and obtain judicial enforcement of remedies to abate pollution or activities damaging ecological conditions. Given the economic disparities between the NGOs, which have little to no funds, and the polluters, which have large funds available for their defence, it will be important for the competent environmental protection administrative departments of the people's government to join the NGOs in prosecuting their suits. Even though the 'costs follow the event' rule when reciprocally applied is no panacea, it may be that the courts will need to develop a practice of awarding as court costs, the attorney fees of the successful plaintiff NGO, to be paid by the unsuccessful polluter. The Supreme Court's guidance to courts in public interest litigation does oblige courts to consider 'the plaintiff's requests for the defendant to compensate for losses ... a as well as reasonable attorney's fees, costs of investigation and evidence collection, appraisal fees and other litigation expenses ... and explore the establishment of a special fund for environmental public interest litigations .... ${ }^{40}$

On 23 June 2014, China's Supreme Court issued its 'Opinion' on 'Comprehensively Strengthening the Judicial Work Concerning Environmental Resources to Provide Strong Judicial Guarantee for Achieving Ecological Progress'. ${ }^{41}$ The Court stresses the need to reverse

$40 \quad$ Fa Fa No. (2014) 11 (23 June 2014) at Paragraph IV.14.

41 Fa Fa No. (2014) 11. These opinions followed decisions in the 18th National Congress and 3rd Plenary Session of the 18th Central Committee of the CPC, and its decision on 'Some Major Issues Concerning Comprehensively Deepening the Reform', by establishing an institutional system to protect the ecological environment. These were advanced further in the 4th CC CCP Plenary. 
the trend of ecological deterioration and build a beautiful PRC for sustainable development of the nation', ${ }^{42}$ The Supreme Court noted that General Secretary Xi Jinping put forth new ideas for society to heed: 'our mountains, waters, forests, farmlands and lakes form a community of life' and 'the people's yearning for a better life is our goal'. The courts are called upon to strengthen their judicial work 'to provide a strong judicial guarantee for future generations of the Chinese to enjoy a sustainable and livable ecological environment'. ${ }^{43}$

The Court notes that the Code of Civil Procedure provides for environmental public interest litigation, and that the Environmental Protection Act clarifies the scope of such litigation. In its Guidelines, the Supreme Court provides that all courts should advance the more stringent resource protection standards, damage compensation systems and provide a strong guarantee of ecological progress. The Court does call for lower courts to 'explore the establishment of systems for environmental remediation and punitive damages and earnestly investigate and affix legal liability to offenders according to law'. ${ }^{44}$

As an instructed judiciary, the courts are to adhere to four 'Basic Principles': (1) adhere to what the law requires for environmental protection; (2) adhere to giving priority to environmental protection; (3) adhere to focusing on prevention of environmental harm; and (4) adhere to the principle of whoever damages bears the responsibility. ${ }^{45}$

In criminal matters, there is to be vigorous prosecution for pollution, deforestation, over-exploitation of wild animals, unauthorized mining, illegal occupation of agricultural lands, sewerage pollution, illegal disposal of solid waste and other crimes. Courts are to develop procedures to try environmental cases and fashion effective remedies. In all matters, the courts are to 'determine the relevant party's burden of proof' ${ }^{46}$ Courts are to accept and hear administrative cases related to environmental resources and 'fully safeguard the relevant party's right to appeal'. Courts should 'strengthen the hearing of cases on failing to perform duties' ${ }^{47}$

With respect to the prospects of citizen suits, the Supreme Court's Opinion calls upon all courts to 'vigorously promote environmental resources-related public interest litigations'. A pollution victim's civil tort or other claims can be advanced independently of public interest

\footnotetext{
$42 \quad I d$., Paragraph I.1.

43 Id., Paragraph I.2.

44 Id., Paragraph II.4.

45 Id., Paragraph II.5.

46 Id., Paragraph III.8.

47 Id., Paragraph III.10.
} 
litigation..$^{48}$ Where multiple parties bring claims, the court that first takes jurisdiction is to hear all the cases. ${ }^{49}$ Innovations in the filing, administration and coordination are to be undertaken in order to promote public interest litigation. ${ }^{50}$

The Court provides that 'if the plaintiff wins the lawsuit, his burden of reasonable attorney's fees, investigation and evidence collection fees as well as appraisal and assessment fees shall be borne by the defendant'. ${ }^{51}$ Use of this provision will be important to make the Chapter $\mathrm{V}$ of the Environmental Protection Law operational, since the handful of NGOs that qualify today to bring citizen suits do not have funds for litigation.

Finally, China's Supreme Court provides measures to 'promote the reform of the judicial system for environmental resources protection in an orderly manner'. The court contemplates establishment of a 'special judicial institution for environmental resources law suits'. ${ }^{52}$ The Higher and Intermediate People's Courts, and some grassroots people's courts, are to establish a special judicial institute for these environmental resources cases. Not all Provinces will have environmental chambers. The Supreme Court wishes to see how they shall operate. Provinces are expected to re-allocate their existing judicial budgets and staff to meet the environmental needs, and new resources will be sought only as the demand is demonstrated by the caseload. When the Supreme Court established its own environmental chamber this year, it did not expand the court, but reassigned functions within the court, and this pattern is likely to be followed throughout the judiciary.

Where appropriate, the Court is studying 'the centralized trial of environmental resources-related criminal, civil and administrative cases'. ${ }^{53}$ Where environmental matters cut across these branches of adjudication, the court signals its intention to coordinate the administration and communication. Eventually, the court is examining how to redraw jurisdictional lines for courts hearing environmental matters to align them with "naturally formed' regions, such as watersheds or ecological zones, or air and water regions. It also is examining how to implement 'centralized management of the environmental resources cases to effectively hear the cases with multi-regional pollution' ${ }^{54}$ Experts in the fields of environmental science

\footnotetext{
$48 \quad I d$., Paragraph IV.11.

49 Id., Paragraph IV.12.

$50 \quad I d$. , Paragraph IV.13.

51 Id., Paragraph IV.15.

$52 \quad I d$., Paragraph V.16.

53 Id., Paragraph V.17.

54 Id., Paragraph V. 18.
} 
and technology and law are to be recruited to advise the courts, serve as mediators and help educate the 'relevant party to realize his error, restore the environment, and compensate for the losses'. ${ }^{5}$

As has been the case in Europe and North America, China's pollution will take years to clean up. Meanwhile environmental restoration efforts will be complicated by the disruptions associated with climate change. Courts can do much to help abate pollution. ${ }^{56}$ The Party, and China's environment, will be well served as it implements the many judicial reforms outlined above. China is in the midst of establishing a system of coordinated, decentralized access to environmental justice for the Chinese people. Whether in China, or any other nation, social peace, public health, and protection of nature depend on the success of such judicial procedures.

\section{IUCN AND THE GLOBAL JUDICIAL INSTITUTE FOR THE ENVIRONMENT}

The enormous scope of environmental judicial reforms launched in China illustrates comparable problems found in most other nations. Few judges ever studied environmental law in their legal education. Few know the leading decisions about how to order effective environmental remediation, after an oil spill, or a chemical fire, or loss of an endangered species' habitat. These are just some of the same environmental law problems that occur in every legal system. Moreover, courts and their judges are not prepared to handle a large volume of environmental cases. Few jurisdictions have the refined judicial procedures that the Land and Environment Court of New South Wales has put into practice for more than four decades. ${ }^{57}$

There is a manifest need for courts to exchange best practices about how to among courts about making scientific findings or incorporating appropriate technologies into remedies. Courts would benefit from sharing standardized computer systems case management. All judicial personnel will need continuing judicial environmental legal education. Awareness of these needs has emerged in the past twenty-five years, as

55 Id., Paragraph VI.20.

56 See World Bank 'Role of the Judiciary in Pollution Management', at http:// siteresources.worldbank.org/INTRANETENVIRONMENT/Resources/2443511279901011064/GuidanceNoteonRoleofJudiciary.pdf.

57 See, e.g., Brian Preston, 'Judicial Specialization: Through Environment Courts: A Case Study of the Land and Environment Court of New South Wales', 29 Pace Environmental Law Review 602 (2012), at https://digitalcommons.pace. edu/pelr/vol29/iss2/10. 
several international and regional organizations began to collaborate with national courts. Prominent among these have been the United Nations Environment Programme (UNEP, now UN Environment), and the World Commission on Environmental Law of the IUCN globally, and the Asian Development Bank (ADB) and Organization of American States (OAS) regionally, and specialized experts such as those of the International Court for the Environment Foundation (ICEF, Rome) or the programmes of the Commonwealth Magistrates' Association (led by Lord Robert Carnwath), Environmental Law Institute (Washington, D.C., USA) or the collaborative work of Pace University's Elisabeth Haub School of Law with the New York Judicial Institute (New York).

UNEP launched the first symposium on the roles of the judiciary for environmental law in Colombo, Sri Lanka, in 1997, under the auspices of the South Asia Co-operative Environmental Programme, with the support of the Norwegian Agency for Development Co-operation. ${ }^{58} \mathrm{~A}$ Compendium of the Summaries of Judicial Decisions in Environment Related Cases (With Special Reference to Countries in South Asia) was published by UNEP for this Symposium. ${ }^{59}$ Leading cases from Bangladesh, India, Pakistan and Sri Lanka, were abstracted along with environmental decisions from courts in Malaysia, Philippines, New South Wales (Australia), Canada, Chile, Mauritius, Kenya, the US, and several rulings from international tribunals. Since the courts in South Asia in the 1990s were the most advanced in environmental jurisprudence, this Symposium was well received. ${ }^{60}$ It led to a subsequent Asian symposium held in Manila, under the auspices of Chief Justice Hilario Davide Jr., of the Supreme Court. Gradually, from these two initial conferences, all regions

58 Donald Kaniaru, Lal Kurukulasuriya, Prasantha Dias Abeyegunawardene, and Chad Martino, editors, Report of the Regional Symposium on the Role of the Judiciary in Promoting the Rule of Law in the Area of Sustainable Development (Colombo, Sri Lanka, 4-6 July 1997). Judges from each South Asia nation spoke, and international speakers included Justice Paul Stein of the Land and Environment Court of New South Wales, Nicholas A. Robinson for IUCN.

59 Editorial advice came from Judge C.G. Weeramantry of the International Court of Justice, and Justice A.R.B. Amerasinghe of the Supreme Court of Sri Lanka, and Justice P.N. Bhagwati, who was then former Chief Justice of the Supreme Court of India. Editors were Donald Kaniaru and Lal Kurukulasuriya for UNREP and Prasantha Dias Abeyegunawardene for SACEP. (Colombo, 1997).

60 The extraordinary judicial decisions of Chief Justice Bhagwati in the 1970s and 1980s is assessed in the symposium published in 16 Banaras Law Journal 1-121 (Issues 1 and 2, 1980). He built, out of administrative law, the first body of environmental case law, which the Supreme Court of India expanded to its later base in constitutional law. 
hosted judicial symposia on environmental adjudication. For example, the North American Commission on Environmental Cooperation held a symposium in Mexico City in 2011, ${ }^{61}$ or the 2016 Third Asian Judges Symposium (with ADB and UNEP) on Law, Policy and Climate Change, in Kuala Lumpur, Malaysia, addressed by IUCN Commission Chair Justice Antonio Herman Benjamin. ${ }^{62}$

IUCN began its work to share knowledge about judicial decision-making on environmental law through the pioneering work of Prof. Charles Odidi Okidi, Vice Chair of the IUCN Commission on Environmental Law, who served as Task Manager for a UNEP/UNDP/Dutch Joint Project for Environmental Law and Institutions in Africa, at the UN Environment Programme. He led the preparation and publication of the Compendium of Judicial Decisions on Matters Related to the Environment in 1998. ${ }^{63}$ In an age before the Internet and when environmental law decisions were not yet compiled or disseminated, the two volumes were important in establishing a common reference for judges on locus standi, environmental impact assessment, public trust doctrine, precautionary principle, polluter pays principle and riparian right to water. Cases were assembled from courts in Australia, Canada, France, India, Kenya, Pakistan, Philippines, South Africa, Tanzania and the USA.

For several years through ICEF in Rome, Justice Amedo Postiglione of the Italian Court of Cassation convened symposia of judges on environmental law, and the need for an international court to adjudicate environmental matters. Although establishment of an international environmental court remains to be realized, Justice Postiglione's conferences and publications produced a rich body of knowledge about national environmental judicial practice. Comparative law studies highlighted the roles that any court could perform. ICEF included IUCN in its meetings, with participation of IUCN Law Commission leaders such as Wolfgang E. Burhenne, Antonio Hermann Benjamin, Nicholas A. Robinson and John Scanlon. ${ }^{64}$

61 https://law.pace.edu/sites/default/files/IJIEA/IJIEABriefingPaper.pdf - this was one of the preparatory thinking studies on the need for a global judicial institute, and was discussed in Mexico City. See also https://www.nycourts.gov/ court-innovation/Winter-2010/jciPowell.pdf.

$62 \mathrm{https} / / / \mathrm{www}$.ajne.org/event/third-asian-judges-symposium-law-policy-andclimate-change\#quicktabs-event_tabs $=1$.

63 The Compendium is in two volumes: Volume I for national decisions and Volume II for International Decisions (ISBN 92-807-1762-6; December 1998).

64 These activities were under the auspices of the International Court of the Environment Foundation (ICEF), Rome, Italy. 
These regional symposia led UNEP to convene the Global Judges Symposium in Johannesburg, South Africa, in 2002. Held on the eve of the World Summit on Sustainable Development, this gathering was the first call to all national supreme courts and high courts to send judges to deliberate together about their judicial approaches to environmental law and sustainable development. The then current and immediate past chairs of IUCN's Environmental Law Commission were invited to participate as experts. The Symposium adopted 'The Johannesburg Principles on the Role of Law and Sustainable Development'. ${ }^{65}$ This declaration affirmed that 'an independent judicial process is vital for the implementation, development, and enforcement of environmental law'. ${ }^{66}$ It called broadly for greater capacity building to enable courts to fulfil their duties better with respect to environmental law legal matters presented to them. As an ad hoc committee of judges was convened to help advance these Principles, and UNEP and partner agencies such as the IUCN Environmental Law Commission, were called upon to assist this process. UNEP's Governing Council endorsed the efforts. ${ }^{67}$

Throughout the past two decades, many judicial symposia were convened. These events permitted national judges to come together, share experiences, and get to know each other. An epistemic community of judges with experience in environmental law emerged. The Green Tribunal of India was established and became a leader both national and internationally, convening its own symposia. The importance of these informal consultations cannot be over-estimated.

By way of illustration, among the symposia are the following:

(a) IUCN held a Symposium on Environmental Law for European Judges in London, in October of 2002. It resulted in the issuance of the 'London Bridge Statement' in May of 2003, which endorsed the IUCN/UNEP Judicial Portal at the IUCN Environmental Law Centre in Bonn, Germany, this being the first Internet database for judges compiling environmental judicial decisions. ${ }^{68}$

65 UNEP, Global Judges Symposium, 2002. See UNEP Annual Report, 2002, at https://wedocs.unep.org/bitstream/handle/20.500.11822/8556/UNEP_Annual_ Report_2002.pdf?sequence $=4 \&$ isAllowed $=y$.

66 UNEP, Global Judges Symposium 2002, at pp. 14-17.

67 UNEP Governing Council Decision 22/17 II A (UNEP GC 22nd Session, Nairobi Feb. 2003).

68 London Bridge Statement, Symposium on Environmental Law for European Judges, convened by IUCN Commission on Environmental Law Vice Chair Andrew Waite, with IUCN Commission Chair Nicholas Robinson and ELC Head 
(b) IUCN's Law Commission later convened a symposium in L'viv, Ukraine, for the Commonwealth of Independent States, organized by IUCN Vice Chair Prof. Svetlana Kravchenko of L'viv University, cosponsored by UNEP. In the same year, UNEP convened a symposium in Buenos Aires for Latin American countries. ${ }^{69}$

(c) In 2004, in Brussels the 'European Forum of Judges for the Environment' was established. This European Forum continues its work.

(d) In Cairo, the 'Arab Chief Judges Regional Conference and Symposium on the Training of Judges and other Stakeholders in Environmental Law and Sustainable Development' was convened in 2004..$^{70}$ Judges from Egypt, Jordan, Lebanon, Libya, Palestine, Sudan, the United Arab Emirates and Yemen launched the Union of Arab Supreme Courts for the Protection of Environment in 2005, ${ }^{71}$ but subsequent political developments across the Arab region have hampered its development.

(e) In Asia, the Asian Development Bank (ADB) convened many judicial symposia and facilitated the establishment of a Forum of Asian Judges on the Environment, which has been active.

(f) In 2004 and thereafter, Pace University in New York, with the New York Judicial Institute, launched several conferences and publications on comparative law and environmental jurisprudence.

(g) IUCN's World Commission on Environmental Law held symposia in Senegal for West Africa and the Francophone community, in Angola for the Luzophone community, and in Seoul Korea for North Asia. There are many other examples of such judicial gatherings, in South America, the Pacific, New Zealand and Australia, Scandinavia and Europe.

These symposia confirmed that, across all regions of the world, courts increasingly encounter environmental law issues. ${ }^{72}$ ADB, UNEP and

John Scanlon, at Adelaide House, London Bridge. London, England, UK; 10-11 October 2002.

69 UNEP Global Judges Programme, at p. 26 (ISBN 92-807-2557-2, 2005).

70 See Mamdouh Marie and Adel Omar Sherif (editors), The Environment and Judiciaries of the Arab World (Supreme Constitutional Court of Egypt and UNEP, 2004, in Arabic and English).

71 Mamdouh Mohey El Dis Marie and Adel Omar Sherif (editors) The Union of Arab Supreme Courts for the Protection of the Environment (UNEP, 2004).

72 See, e.g. Alec Stone Sweet, The Judicial Constitution of Europe, chapter 5, 'Environmental Protection', with Markus Gehring (Oxford University Press, 2004). 
IUCN, along with many others, provided support for these judicial exchanges, as far as their scarce resources permitted. Since national courts have no budget to permit their judges to travel or attend such meetings, the modest support for the symposia from international bodies made their success possible.

It became clear that national courts would need to define their procedures and priorities, as the People's Republic of China is doing, in order to build their own capacity to deal with environmental adjudication. To facilitate the roles of national courts to collaborate, the IUCN World Commission on Environmental Law came to provide the critical catalytic role. Where other inter-governmental organizations were constrained by their mandates, IUCN's more flexible framework enabled it to be a convener of courts to establish a new global institution that would enable national courts to address how to enhance their respective capacities for environmental adjudication.

Resolving environmental problems invariably requires a long-term focus and many incremental decisions. Courts need to build a sustained capacity to cope with the legal issues about sustainable development and climate change impacts. Just as the nineteenth century's laws for protected areas were once deemed novel, so today the environmental law remedies through courts are equally regarded as novel. With the nations of the Earth holding 5 billion more humans since environmental issues became matters of national and international law at the end of the nineteenth century, courts have more environmental matters to decide in the twenty-first century than ever before. It will take more than one generation for these judicial procedures and their remedies to become widely deployed.

Over the past 25 years, IUCN's Law Commission has worked with judges to explore how to build collaboration among national courts. In 2003, IUCN's Commission on Environmental Law launched a judicial specialist group to address these needs in the 1990s, and to collaborate with the United Nations Environment Programme in the convening of symposia for judges in all regions. Chief among these was the 2002 UNEP 'Global Judicial Symposium on Sustainable Development and the Rule of Law', in Johannesburg. UNEP published a further Compendium of Summaries of Judicial Decision in Environmental Related Cases ${ }^{73}$ based on the one that had been published for the 1996 Sri Lanka symposium. The Johannesburg symposium was a dramatic

73 UNEP, Policy Series 4, August 2002 (UNEP Division of Policy Development and Law), republished in 2005 as ISBN 92-807-2557-2, 2005. 
acknowledgement of the benefits for all of international cooperation to strengthen environmental adjudication in all courts. ${ }^{74}$ It inspired others to hold similar meetings. For example, the International Symposium on the Judiciary and Environmental Law in Mexico, the US and Canada, held with the UNEP Regional Office for Latin America and the Universidad Panamericana. ${ }^{75}$

Several further symposia for judges followed. ICEF convened in Rome a symposium on 'Johannesburg Summit Next Steps', in May of 2003. ${ }^{76}$ Senior IUCN Law Commission officers, Wolfgang E. Burhenne, Nicholas A. Robinson, and Antonio Herman Benjamin, participated. UNEP disseminated publications about environmental adjudication. Two IUCN scholars, Alexandre Kiss and Dinah Shelton, contributed their scholarship to UNEP, which enabled UNEP to publish a Judicial Handbook on Environmental Law. ${ }^{77}$ Finally, when the IUCN World Conservation Congress in 2012 elected Justice Antonio Herman Benjamin, judge of the Superior Tribunal do Justiça (the National High Court of Brazil ${ }^{78}$ as the Chair of IUCN's Environmental Law Commission, IUCN became well placed to provide focus and collaborative leadership to bring courts around the world into global cooperative relationships.

In order to provide a framework for providing global judicial con-

74 Report of the Global Judicial Symposium at https://digitallibrary.un.org/ record/484610. Environmental law leaders such as UNEP's Donald Kaniaru, later an environmental court judge in Kenya, and IUCN Law Commission Chairs, Dr. Parvez Hassan and Prof. Nicholas Robinson, participated in the Johannesburg Symposium. UNEP's Lal Kurukulasuriya had convened the first symposium in 1998 in Sri Lanka, at which IUCN Commission Chair Nicholas Robinson provided lectures. IUCN convened later symposia in London (West Europe), in L'viv, Ukraine (Central Europe and Eurasia), and in Seoul, Korea (North Asia). UNEP convened symposia in all other regions. Regional symposia in Asia have been convened by the Asian Development Bank, and in South America by the Organization of American States (OAS). The Environmental Law Institute (Washington, DC) has held national judicial capacity programmes in Uganda, Mexico and elsewhere for more than two decades.

75 29-30 November 2005, Mexico City under the auspices of the Commission on Environmental Cooperation, with specialists such as John Cruden, Paul Gavrel, Nicholas A. Robinson. Scott Fulton, Neofito Lopez, Juan Carlos Ortega, Timothy Whitehouse, and others.

76 Many papers were prepared for this symposium. See, e.g. the contribution of the Italian Constitutional Court, Division of Studies, Mario Bellocci, 'Italian Constitutional Jurisprudence: Main Principles on the Environment', 9 April 2003, STU 163.

77 Dinah Shelton and Alexandre Kiss, Judicial Handbook on Environmental Law (ISBN 97-807-2555-6, 2005).

78 http://www.stj.jus.br. 
tinuing environmental law cooperation and education, IUCN's World Commission on Environmental Law made the courts a major focus of its work. Led by Justice Antonio Herman Benjamin the Commission proposed the establishment of a Global Judicial Institute on the Environment at the IUCN World Conservation Congress held in Jeju, Korea. Justice Benjamin organized the IUCN World Commission on Environmental Law to convene many consultations of judges in Africa, Asia, Latin America and elsewhere, in close collaboration with UNEP, ADB, OAS and others. Other partner organizations did the same, and environmental law symposia of judges proliferated. The International Association of Judges also decided to cooperate in enhancing capacity for environmental adjudication.

Building on the many, diverse symposia and judicial gatherings, IUCN recognized that a consensus had emerged favouring the establishment of a Global Judicial Institute on the Environment (GJIE) ${ }^{79}$ Justice Benjamin took advantage of the IUCN 1st World Congress on Environmental Law held in 2016 in Rio de Janeiro, ${ }^{80}$ to convene judges from around the world. In separate meetings that were held in parallel with select sessions of the 1st World Congress on Environmental Law, the judges called for the creation of the GJIE. IUCN's World Conservation Congress had endorsed establishment of the GJIE. ${ }^{81}$ Creation of GJIE was a signal accomplishment of the 1st World Congress on Environmental Law. It was a culmination of the efforts that UNEP began in 1998, with IUCN, and the efforts that IUCN's Environmental Law Commission began in $2002 .^{82}$ The consultations among courts around the world had produced the fertile ground in which the seeds for the GJIE sprouted. The nourishment for the concept, and the essential catalyst for creation of the GJIE, has been Justice Benjamin and his tireless leadership.

79 https://www.iucn.org/news/world-commission-environmental-law/201607/ judges-establish-global-judicial-institute-environment.

80 https://www.iucn.org/commissions/world-commission-environmental-law/ events/27-29-april-2016-world-environmental-law-congress.

81 WCC-2016-Res-071, Resolution 079, at https://portals.iucn.org/library/sites/li brary/files/documents/IUCN-WCC-6th-005.pdf.

82 Barbara J. Lausche, Weaving $A$ Web of Environmental Law, at p. 395, and passim, (2008), see https://www.iucn.org/content/weaving-web-environmentallaw for the IUCN preparatory phases for the GJIE. The UN Environment Programme (UNEP) and Asian Development Bank (ADB) also convened symposia of judges to begin international cooperation among courts on environmental law. 
The governance and programmes for the new GJIE have been progressively advanced. The second meeting of the GJIE was held in $2017,{ }^{83}$ and the third in $2018 .^{84}$ Judges met to prepare the statute for the GJIE, and then to select the initial governing board of judges. UNEP and the GJIE signed an exchange of letters for UNEP to provide support for the GJIE's initial secretariat. As of 2018, the GJIE is primed to begin its capacitybuilding for judges through offices at headquarters of UN Environment in Kenya. The Charter and Statutes of the GJIE make it clear that it is a body led by judges, for judges. It has been registered in Geneva as an international organization. It is autonomous. It will build the capacity of judges around the world to adjudicate environmental law issues.

The GJIE is thus well positioned to work with other institutions that promote judicial capacity, such as the Asian Development Bank and the Organization of American States, or the International Association of Judges. It can draw on the work of the America Bar Association's Rule of Law Initiative (ROLI), with its Rule of Law Index, which assesses best practices and measures the environmental rule of law. The GJIE can advance the norms for the 'environmental rule of law' adopted by the UN Environmental Assembly, ${ }^{85}$ and the programmes of UN Environment (formerly UNEP), ${ }^{86}$ the World Commission on Environmental Law of the International Union for the Conservation of Nature \& Natural Resources (IUCN),${ }^{87}$ the Asian Development Bank ${ }^{88}$ the Organization of American States, ${ }^{89}$ and by specialized entities such as the Environmental Law

83 https://www.iucn.org/news/world-commission-environmental-law/201705/ second-international-meeting-global-judicial-institute-environment.

84 For all information on the GJIE see https://www.iucn.org/commissions/worldcommission-environmental-law/our-work/global-judicial-institute-environment.

85 United Nations Environment Programme, Global Symposium on Environmental Rule of Law, www.unep.org/unea/erl/asp.

86 UNEP Global Judges Symposium on Sustainable Development and the Role of Law, http://www.unep.org/law/Symposium/Judges_symposium.htm.

${ }_{87}$ Thomas Greiber, ed., Judges and the Rule of Law: Creating the Links: Environment, Human Rights and Poverty (IUCN Environmental Policy and Law Paper 60, 2006), at https://portals.iucn.org/library/efiles/documents/EPLP-060. pdf.

ADB, Asian Judges Symposium on Environmental Decision Making, the Rule of Law, and Environmental Justice: The Proceedings of the Symposium (Manila (2011).

89 OAS Environmental Law, Policy and Governance, Working Group on Strengthening Judicial Institutions and Jurisprudence (8 recommendations on environmental judicial capacity-building), at www.oas.org/EN/SEDI/DSD/ELPG/resou rces/strengtheingjudicial.asp. 
Institute, ${ }^{90}$ law schools ${ }^{91}$ or programmes like the Access Initiative under the World Resources Institute. ${ }^{92}$ Regional networks of judges on the environment in Europe, ${ }^{93}$ in Asia ${ }^{94}$ and elsewhere, have much to contribute to the forthcoming programmes of the GJIE.

This brief account of how human societies increasingly are mobilizing support for creating new environmental courts is a further confirmation that human society seeks justice for its relations with nature. It is in the nature of courts that their judges seek to do justice, and this extends to the community of life. Of course, this quest for justice fails or is frustrated when courts are denied their capacity to do so. The reasons are varied. Corruption impedes environmental justice. Indonesia has established a court to root out corruption. ${ }^{95}$ Some courts, such as those in the USA, set artificially high thresholds for locus standi that can preclude access to justice. ${ }^{96}$ Some courts are unnecessarily bound to the executive branch, as seen in some former Soviet Union Republics. Some environmental legal systems preclude public interest litigation, as in Singapore, which has no law for EIA. The GJIE can address some aspects of building judicial capacity, but not all.

90 ELI, Judicial Education Program, at www.eli.org/judicial-education.

91 See, e.g., Pace University School of Law, Global Center for Environmental Legal Studies, programme, with Commission on Environmental Cooperation for State and federal Judges of Canada, Mexico and the USA, with the New York State Judicial Institute, 2004, at www.law.pace.edu, and www.newswire.blogs.law. pace.edu/2004/12(06); or the Sturm College of Law at the University of Denver, Environmental Courts \& Tribunals (ETC) project, http://siteresources.worldbank. org/INTRANETENVIRONMENT/Resources/244351-1279901011064/Guidance NoteonRoleofJudiciary.pdf.

92 George and Catherine Pring, Greening Justice: Creating and Improving Environmental Courts and Tribunals, http://www.accessinitiative.org/resource/green ing-justice (2009).

93 See L. Lavrysen, 'Access to Justice in Environmental Matters - Perspectives from the European Union Forum of Judges for the Environment', prepared for the conferences in Iguacu (12 Nov. 2014) and Brasilia (14 Nov. 2014).

94 Asian Development Bank, 'Environmental Governance and the Courts in Asia', ADB Law \& Policy Reform, Brief No, 1 (June 2012).

95 Sofie Arjon Schütte and Simon Butt, 'The Indonesia Court for Corruption: Circumventing Judicial Impropriety', (2013, Chr. Michelesen Institute, Bergen) at https://www.u4.no/publications/the-indonesian-court-for-corruption-crimes-circum venting-judicial-impropriety.

96 See Karl Coplan, 'Citizen Litigants Citizen Regulators: Four Cases Where Citizen Suits Drove Development of Clean Water Law', 25 Col. Nat. Res., Energy \& Envt'l L. Rev. 63 (2014), at https://www.colorado.edu/law/sites/default/files/Coplan $\%$ 20Citizen $\% 20$ Litigants $\% 20$ Citizen $\% 20$ Regulators\%2025.1.pdf. 


\section{E. DELIBERATING JUSTICE: ANTICIPATING COMPARATIVE LAW STUDIES FOR ENVIRONMENTAL COURTS}

With the creation of GJIE, a watershed has been reached. In place of the first generation of judicial symposia, there will be a flowering of comparative legal studies on environmental adjudication. Of what might this forthcoming body of comparative judicial decision-making in environmental law consist? What reforms will it stimulate? The GJIE can facilitate the sharing of judicial decisions across legal systems and languages. Since the Earth's biosphere is singular, and environmental laws are congruent around the world, as courts address issues of nature anywhere, there will emerge one shared understanding of environmental justice. Inconsistent approaches to protecting nature will be seen to impair the whole. Comparative study of judicial practices can build a more consistent approach to how court decisions affect nature.

Consider the example of Brazil. During the military government in Brazil, the courts were subservient to the government, and were constrained. The guarantees of Brazil's 1988 constitution ensure judicial independence in many ways. This constitution has opened space for judges to explore remedies tailored to remediate the wrongs. Brazil's National High Court (Superior Tribunal de Justiça) has delivered a number of landmark judicial decisions, giving effect to the Constitutional Article on environmental rights. For example, Justice Paulo de Tarso Sanseverino, as the Relator for the High Court, issued a decision in the Private Law Division (2nd Division) that expressly employed the principle of 'in dubio pro natura' as an analytic rule of interpretation. The Public Law Division (1st Division) has provided several landmark environmental decisions, including those of Justice Antonio Herman Benjamin. ${ }^{97}$

The importance of the principle in dubio pro natura, is that it shifts the presumption away from a preference or bias for human activity that harms nature, often in the name of exercising claims or property rights or economic rights, and deferring to norms of sustainability and acknowledging shared values by averting undue impacts on ecosystems..$^{98}$ This principle acknowledges that attaining justice in environmental cases

97 See the analysis in Nicholas S. Bryner, Brazil's Green Court: Environmental Law in the Superior Tribunal de Justiça (High Court of Brazil), 29 Pace Envtl. L. Rev. 470 (2012). Available at: http://digitalcommons.pace.edu/pelr/vol29/iss2/4.

98 See the Anais do I Encontro Interncional de Direito Ambiental, 'In Dubio Pro Natura', 7-11 August 2012 (Manaus) Association of Brazilian Magistrates (AMB), 2013. 
requires anticipating all the ecological interests that are not represented before a court. Justice requires respecting the environmental interests of the community of life beyond the narrow purview of the parties in a single case.

In addition to Brazil's court, the courts of South Asia have had strong traditions of judicial innovations in environmental cases since the 1980s. For example, the use of Suo Moto jurisprudence in the courts of Pakistan, by which when judges see unjust conditions, they have the capacity to initiate remedial court proceedings when good cause is evident. This extends to issues of justice and climate change. ${ }^{99}$ When governmental authorities are not addressing evident environmental harms, unjust conditions and injuries are exacerbated. ${ }^{100}$ India's Supreme Court, has the leading body of environmental case law of any Supreme Court worldwide. ${ }^{101}$ Its precedents are emulated by other Supreme Courts across South Asia. This tradition is currently furthered and enhanced by the work of the Green Tribunals in India.

The environment courts in New Zealand and in New South Wales are the oldest in any region. Australia has a remarkable body of case law beginning more than four decades ago. In New Zealand in 2014, the Supreme Court decided the King Salmon case, applying a rule of strict environmental protection to that nation's coastal natural resources planning provisions. ${ }^{102}$ This ruling reverses prior approaches to adjudication that had looked very narrowly at decisions, avoiding considerations of impacts on nature. ${ }^{103}$ King Salmon now opens the door in New Zealand for courts to consider applying rules of interpretation like the in dubio pro

99 Parvez Hassan, 'Judicial Commissions and Climate Justice in Pakistan', (Feb. 2018, Asia Pacific Judicial Colloquium on Climate Change, Lahore), at http://www. pja.gov.pk/system/files/4\%20- $\% 20$ Judicial $\% 20$ Commissions $\% 20$ and $\% 20$ Climate $\% 2$ 0Justice $\% 20 \mathrm{in} \% 20$ Pakistan $\% 20 \% 28 \mathrm{Feb} \% 202018 \% 29 \% 20-\% 2$.

100 See, e.g. Suo Moto case No 25 of 2009 (Cutting of Trees for Canal Widening Project, Lahore), Judgment of the Supreme Court of Pakistan (Original Jurisdiction, August 15, 2011), following mediation by Dr. Parvez Hassan.

101 See, e.g. Anita Yadav, Role of Supreme Court of India in Protection of Environment (2011), at https://www.researchgate.net/publication/228264905_ Role_of_Supreme_Court_of_India_in_Protection_of_Environment. Further to this research, as with any jurisdiction, it is worth investigating whether implementation and enforcement efforts match the quality of judicial decisions.

102 Environmental Defense Society Inc. v The New Zealand King Salmon Co Ltd [2014] NZSC 38.

103 See, e.g. West Coast Ent Inc, v. Buller Coal Ltd et al. SC75/2012, [2013] NZSC 87 (19 September 2013) in which the Supreme Court had reversed a ruling of NZ Environment Court, affirmed by the Hjgh Court, and ruled that a consent granted for an open-cast coal mine did not have to examine that fact that the coal 
natura principle. In contrast, the Land and Environment Court of New South Wales has consistently taken a more expansive view of justice, by embracing a holistic environmental perspective informed by the ecological and other sciences. This New South Wales Court has earned a welldeserved reputation for being among the most effective environmental courts, worldwide. ${ }^{104}$ The rulings from New South Wales constitute a sustained corpus of decisions and effective court procedures that reach environmental justice. Its use of the precautionary principles shares similar juridical roots to the in dubio pro natura maxim in Brazil's High Court.

The emerging jurisprudence of environmental courts lays the foundation for recognizing further environmental principles. For example, in legislation on sustainability, or environmental impact assessment, rulings implicitly touch upon ecological relationships and their mutually re-enforcing dimensions. There is scope to recognize the Principle of Resilience, which is implicit in such environmental cases. ${ }^{105}$ A stronger recognition of legal rights inherent in nature is found in the Extraordinary Writ of Kalikasan (Nature), promulgated by the Supreme Court of the Philippines. In the Philippines, the Supreme Court has promulgated rules of procedure establishing an Extraordinary Writ of Nature, which shifts the burden proof onto the party alleged to be damaging the environment to prove that it is compliant with all applicable environmental laws. ${ }^{106}$ Where extreme environmental degradation exists, such a procedure and remedy averts further harm and open the door to realizing the remedial justice measure to restore environmental well-being for humans and nature.

Where courts make decisions in isolation of each other, parochial narrowness results. Courts can fail to reflect environmental justice in their rulings. The US Supreme Court is a good example. Its decisions emasculated the substantive mandates of the Section 102 of the National Environmental Policy Act of 1969 (NEPA), to affirmatively avert or mitigate adverse environmental impacts revealed by EIA. ${ }^{107}$ The Court has

would be burned and have an impact on climate change, and need only look at the environmental aspects of the mining operations narrowly.

104 See http://www.lec.justice.nsw.gov.au.

105 Nicholas A. Robinson, 'The Resilience Principle', 5 IUCNAEL EJournal 19 (2013), at www.iucnael/ejounral.

106 Writ of Kalikasan, Supreme Court of the Philippines, A.M. No 09-6-8-SC.

107 Richard Lazarus, The Making of Environmental Law (2002). See also R. Lazarus, 'The National Environmental Policy Act in the U.S. Supreme Court: A Reappraisal and a Peek Behind the Curtains', at http://www.law.harvard.edu/faculty /rlazarus/docs/articles/Lazarus_APeekBehindtheCurtain_2012.pdf. 
ruled that any executive agency should be free to harm the environment if its projects warrant doing so, after it completed a detailed written environmental impact statement exposing the potential harm. The environmental policies of Section 101 were deemed aspirational and non-binding even though the original intent of NEPA was to mandate the agency to avoid environmental harm, once studied and made known.

Today, virtually every nation has enacted national EIA statutes. This situation is now ripe for comparative environmental law analysis. The International Court of Justice has ruled that customary international law requires all States to prepare such assessments. ${ }^{108}$ Principle 17 of the Rio Declaration on Environment and Development mandates use of EIA in all national environmental decision-making. ${ }^{109}$ How much substantive mitigation should EIA require? California and New York, whose 'little NEPA' statutes predate the Supreme Court's re-interpretation of NEPA, still honour the substantive mitigation rule, but repeatedly in both States judges have been reluctant to curb economic development in the name of nature protection. The federal court decisions are cited in cases in the States to weaken the substantive mandates of California Environmental Quality Act (CEQA) ${ }^{110}$ or the New York State Environmental Quality Review Act (SEQRA). ${ }^{111}$ These regressive EIA judicial decisions should be subjected to wider comparative law analysis.

Since EIA embodies a proactive, global legal norm to protect the environment, and its procedures are virtually universal and similar in all nations, EIA is a prime example where courts should compare each other's practices and rulings. When courts apply different standards of care while adjudicating environmental issues, the result measures justice inconsistently. The result is measurable environmental harm. When courts diminish nature as a focus of justice, they lose part of their legitimacy in the eyes of the public. How courts affect the environment matters. Since people innately seek justice, and have evolved to recognize the need to do what is just for the entire community of all life, not just human life, then surely a court that is blind to these dimensions of justice will watch its authority erode. Ultimately, the rule of law is diminished.

108 Pulp Mills on the River Uruguay (Argentina v. Uruguay) 2010, at http://www. icj-cij.org/en/case/135/judgments.

109 http://www.un.org/documents/ga/conf151/aconf15126-1annex1.htm.

110 Cal. Public Resources Code, Sections 21000 et seq.; see the discussion of CEQA at http://ohp.parks.ca.gov/?page_id=21721.

111 NYS Environmental Conservation Law, Article 8; see the discussion of SEQRA at https://www.dec.ny.gov/permits/357.html. 
Just as the Magna Carta and the Forest Charter required centuries of struggle to become acknowledged as the norm, it will take constant efforts before EIA is observed as an integral element of the environmental rule of law. In the long run, either courts bring society more consistently to attain to environmental justice, or the environmental disruptions of the Anthropocene will prevent and pervert justice.

The insights of the nineteenth-century religious leader Theodore Parker suggest that today's crescendo for expanding and enhancing the numbers and roles of environmental courts and tribunals will continue. $\mathrm{He}$ observed, in another age worrying about the need to abolish slavery:

Look at the facts of the world. You see a continual and progressive triumph of the right. I do not pretend to understand the moral universe, the arc is a long one, my eye reaches but little ways. I cannot calculate the curve and complete the figure by the experience of sight; I can divine it by conscience. But from what I see I am sure it bends towards justice. ${ }^{112}$

Parker's views emanate from a sense of natural law. They could just as well reflect Darwinian evolution. They reflect Aldo Leopold's instincts about the community of life. Humans are adapting culturally to the Anthropocene by creating social institutions to promote environmental justice, a prerequisite for survival.

Courts are essential to maintaining ordered liberty. Many courts have recognized the right to the environment. At their best, courts oblige all to follow due process of law. By adjudicating human conduct against basic norms, such as the duty to protect nature, courts maintain social order and environmental balance. Courts are transparent, open and are seen to be doing justice. When many may be victimized by the disruptions of the Anthropocene, social order will increasingly depend on environmental judicial decision-making.

\section{F. CLOSING REFLECTIONS}

As Earth's environmental problems grow and are better understood, the quest for environmental justice becomes ever more important. Courts can attain fair and equitable decisions if they read justice broadly, as Aldo Leopold urged with the 'land ethic'. It is unjust to read justice narrowly. When the US Supreme Court upheld the unjust regime of slavery in the

112 Theodore Parker, Ten Sermons of Religion, Of Justice and the Conscience (1853), Crosby, Nichols and Company, Boston. 
Dredd Scott case, in $1857,{ }^{113}$ it led to the American Civil War. When courts blindly upheld segregation in America, judicial injustice led to riots and the enactment of the Civil Rights laws.

Courts are aided in reading justice broadly by hermeneutic rules of statutory interpretation and adjudication, such as in application of the principle in dubio pro natura. Pennsylvania's Supreme Court gave effect to the Commonwealth's Constitutional right to the environment when it ruled that local authorities have constitutional justification to enact local laws to ban hydraulic-fracturing ('fracking') anywhere in their municipality, to avert the harm to the environment, even when a private property owner has title to the land where fracking was to be undertaken. ${ }^{114}$ Where courts do not recognize such a right to the environment, the private property owner prevails, as when Colorado's Supreme Court overturned the local ban on fracking by the town of Colorado Springs. ${ }^{115}$

Since it is in the nature of courts to be conservative, not timid but cautious, courts need to be confident that they understand the environmental context of matters before them. Adjudication of environmental matters, whether in conserving nature or respecting human environmental rights, is a conservative and principled juridical function. Stabilizing or restoring the environmental status quo supports the principle of sustainable development. Actions otherwise do not.

Courts need recourse to a principled and robust environmental jurisprudence, in order to maintain the independence to withstand economic pressures for unsustainable development. This happens when the public urges adherence to the environmental rule of law as a human right, ${ }^{116}$ and

113 https://www.britannica.com/event/Dred-Scott-decision.

114 Robinson Township, et al., v. Commonwealth of Pennsylvania, et al. 52 A. 3d 462 (2012). See https://scholar.google.com/scholar_case?case $=13778976762266531$ $337 \& q=$ Robinson+Township+Pennsylvania +Fracking\&hl=en\&as_sdt=6,33\&as_ vis $=1$. The local municipal ordinance to prohibit fracking were upheld.

115 The Colorado Supreme Court overturned local bans on fracking by two towns. See City of Longmont v. Colo. Oil and Gas Ass'n (interpreting constitutional provisions on Preemption and Inalienable Rights), 2016 CO 29 No. 15SC667 (2014). See https://www.courts.state.co.us.

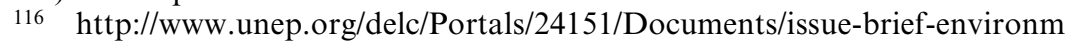
ental-justice-sdgs.pdf. UNEP describes its advisory committee on environmental justice thus: 'The UNEP International Advisory Council for Environmental Justice and other voices have repeatedly underscored the increasing number of examples from around the world that the rule of law and sound institutions are essential for societies to respond to increasing environmental pressures in a way that respects fundamental rights and principles of justice and fairness, including for future generations and across national borders. These examples also show that in the absence of environmental rule of law, key objectives of good governance 
a foundation for justice. In the same vein, other branches of government should respect the roles of courts. Most courts lack independent sources of funds to operate, and are beholding to the budgets adopted by the executive and legislative branches. Courts have limited enforcement capacity, and rely on the executive branch to secure observance of judicial ruling when disobeyed. Thus, unless the fundamental roles of courts are clear, they are unlikely to be capable of exploring concepts of justice, whether for environmental or other subjects. The GJIE cannot be expected to relieve environmental courts of these challenges. It can build judicial capacity to cope with environmental justice.

When humans more widely embrace Leopold's 'land ethic', and recognize nature is humanity's home, then courts will recognize these norms and that leads to environmental justice. Specialized courts for the environment will help all courts and society, move toward realizing environmental justice. This is not an abstruse or idealistic aspiration. It is happening today, in the decisions of the environmental courts and tribunals of many nations.

This should not be surprising. Most courts, but not yet all, acknowledge basic procedural rights to a person accused of a crime. They accord each person the same dignity and basic human rights. Courts are finding the right to water to be a human right. ${ }^{117}$ It is not far-fetched for courts to recognize rights to clean air, or to ecosystem services, or to a robust procedure for environmental impact assessment and ensuring public participation and access to justice in environmental decision-making. The courts, like all human institutions, exist in nature's realm. When a court acknowledges the ecological setting of the forest, or marsh, or stream or sea or mountain, it is bound to do justice for humans within the entire community of life. When judges recognize that nature is entitled to justice, then it will be in the nature of courts to seek to do justice for nature.

cannot be realized. Public participation in decision-making, transparency, and accountability of all persons, institutions and entities, both public and private and including the State itself, rely on the supremacy of the law, as embodied in the environmental rule of law.'

117 UN General Assembly Resolution 64/292 (28 July 2010): recognizing the human right to water and sanitation and that clean drinking water and sanitation are prerequisites for all human rights. 